possibility of utilizing household by-products (dressmakers' scraps, etc.)

Note German method of enclosing blankets (or feather bed used for covering!) completely in washable slip, as sanitary protection of less easily washed portions of bed coverings.

\title{
HOUSEHOLD MANAGEMENT IN THE HIGH SCHOOL."
}

By Bernice Allen, University High, University of Chicago.

Last year was my first experience in teaching Household Management to high school girls. The class met for single periods ( 45 minutes) every day for one semester. Our class room was a cooking laboratory.

In planning the course, I realized I would deal with a class of girls which would have had practically no experience with household affairs, and moreover, who had not yet reached the age when they thought it necessary they should know about such matters. Since there were no prerequisites to the course the foundation upon which to build was very uncertain. Thinking that each girl's experience would be sufficient for her to know that preparation of food and cleaning were two large factors in household operations, I decided to group my ideas around these two lines of activity, keeping in mind at all times their scientific, economic and civic aspects, and considering the relative values of the different household activities.

When the class assembled, I found that the girls had very vague notions of what the course ought to teach them. However, several expressed a desire to know how to plan meals and to know what balanced meals were. According to the girl's ideas of how much ought to be spent per day for herself for raw food material, and for food which she thought would nourish her sufficiently, the lowest estimate was $50 \mathrm{c}$, the highest $\$ 1.00$.

Thereupon followed a study of what foods are; what they contain; what they cost; what calories are; how many calories a day's rations should contain. Then came questions asking how much carbohydrate, protein, etc., should these menus contain? What were the consequences if menus contained too much carbohydrate or too much protein? These and other questions

\footnotetext{
1Read before the Home Economics Section, Central Association, Hyde Park High School, Chicago, Nov. 27, 1914.
} 
carried me farther into the subject than I intended to go, but because of the intelligent interest the girls were displaying and my own curiosity in seeing how far I could take them, I proceeded by the 100 calorie method to teach them to plan menus. Considering the age and size of the girls, I gave them 2500 calories as the approximate number for their day's rations, and asked them to estimate the cost. When the papers were brought in there was considerable distress expressed over the fact that the meals didn't cost enough-the prices ranged from $20 \mathrm{c}$ to $50 \mathrm{c}$. Next I asked them to modify their rations to conform to the rule that $10-15 \%$ of the calories should be protein. The menu which came the nearest to meeting requirements was placed on the board for criticism. The ment was as follows:

\begin{tabular}{|c|c|c|c|c|c|}
\hline $\begin{array}{r}8 \\
8 \\
0 \\
\end{array}$ & 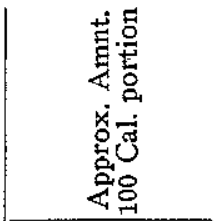 & 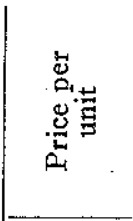 & 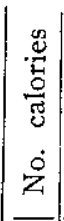 & ठ & $\begin{array}{l}\text { bo } \\
.5 \\
\stackrel{5}{0} \\
\stackrel{5}{\circ}\end{array}$ \\
\hline \multicolumn{6}{|l|}{ BREAKFAST } \\
\hline 1 banana...... & 1 large & $20 \mathrm{c}$ doz. & 100 & .0160 & 1.3200 \\
\hline 2 eggs-poached $\ldots \ldots \ldots$ & $1 \frac{1}{2}$ & $40 \mathrm{c}$ doz. & 130 & .0666 & 12.614 \\
\hline a thin slices bread, toasted. & 1 thick slice & $5 \mathrm{c}$ loaf & 100 & .0060 & 3.600 \\
\hline \multicolumn{6}{|l|}{ LUNCHEON $\ldots \ldots \ldots \ldots \ldots$} \\
\hline Boiled ham...$\ldots \ldots \ldots$ & 1 large slice & $40 \mathrm{clb}$. & 300 & .0936 & 21.450 \\
\hline $\begin{array}{l}\text { Potatoes } \ldots \ldots \ldots \ldots \ldots \\
\text { Macaroni and cheese: }\end{array}$ & 1 large & $25 \mathrm{c} \mathrm{pk}$. & 100 & .0080 & 2.690 \\
\hline Macaroni.............. & $\frac{1}{4} \mathrm{c}$. & $10 \mathrm{c}$ pkg. & 100 & .0080 & 3.700 \\
\hline Cheese.... & $1 \frac{1}{2}$ in. cube & $28 \mathrm{c} 1 \mathrm{~b}$. & 100 & .0140 & 6.500 \\
\hline Milk.. & $\frac{5}{8}$ cup & 9c qt. & 50 & .0066 & 2.380 \\
\hline Flour.............. & $4 \mathrm{lb}$. & 4c $1 \mathrm{~b}$. & 25 & .0005 & 0.793 \\
\hline Butter. & $1 \mathrm{lb}$. & & 100 & .0020 & 0.130 \\
\hline Bread & $\cdots \cdot$ & .. & $\mid 100$ & .0060 & 3.600 \\
\hline Butter . & & & 100 & .0020 & 0,130 \\
\hline \multicolumn{6}{|l|}{ DINNER } \\
\hline Lamb chop. & $\frac{1}{3}$ chop & $28 \mathrm{c} \mathrm{lb}$. & 300 & .0594 & 17.580 \\
\hline Peas & $\frac{3}{8} \operatorname{cup}$ & $15 \mathrm{c}$ can & 50 & .0215 & 3.260 \\
\hline Po & ‥ & .. & 100 & .0080 & 2.690 \\
\hline $\mathrm{Brc}$ & & & 100 & .0060 & 3.600 \\
\hline Butt & & & 150 & .0030 & 0.195 \\
\hline Lettuce .: & 2 large heads & 10c head & $\begin{array}{r}5 \\
\end{array}$ & .0100 & 0.314 \\
\hline $\begin{array}{l}\text { Olive oll } \\
\text { Vinegar. }\end{array}$ & $\begin{array}{l}1 \\
\frac{1}{2} \\
\frac{1 b}{2} \mathrm{lb} .\end{array}$ & $\begin{array}{l}80 \mathrm{c} \mathrm{qt} \\
30 \mathrm{c} \text { gal. }\end{array}$ & 200 & .0330 & \\
\hline \multicolumn{6}{|l|}{ Custard: } \\
\hline Milk. . & & & 100 & .0132 & 4.760 \\
\hline Egg & & & 65 & .0330 & 6.307 \\
\hline 等 & $2 \mathrm{Ib}$ & & 501 & .0036 & \\
\hline & & & 75 & .44 & \\
\hline
\end{tabular}

$15 \%$ of $2675=401.25$.

$98.078 \mathrm{~g} \cdot \mathrm{x} 4=392.312$ calories of protein. 
The menu was prepared and served. A study of the menu and the prepared food brought forth the following criticisms which made me feel that the study had been worth while.

1. The protein although within the $15 \%$ limit was rather high.

2. Expensive forms of protein were chosen.

3. A cereal might have been substituted for one of the eggs for breakfast, thus reducing both cost and protein.

4. The amount of ham served was more than one person would care for ordinarily. Considering that both macaroni and cheese contain protein, the ham could be eliminated altogether. Cheese is a cheaper form of protein than meat.

5. That chops are an expensive form of meat but are more easily prepared than other less expensive cuts of meat.

6. A dessert less expensive and less rich in protein might have been selected.

In addition to this study of food where the girl was considering chiefly her own tastes and desires, we made some study of how these same factors-fuel value, cost, etc., were of practical use in institutions and charitable organizations; that such men as Chapin and others had made detailed studies of foods, finding that the minimum price for food which would furnish the requisite amount of energy was from $21 \mathrm{c}$ to $25 \mathrm{c}$ per day per person.

I will mention a few other things which I tried and which I felt were fairly successful.

After studying heating apparatus and ventilation, the engineer took us around the school building and explained the mechanism of the steam heating system. When studying the water supply we made a trip across the campus to the filtration plant where the water used for drinking purposes at the university is filtered.

As an example of how to economize in expenditures of energy in the kitchen, I asked each girl to make a plan of her kitchen at home. Then I asked for another plan showing how by rearrangement of furniture and equipment a large number of steps might be saved. This problem was not entirely satisfactory because I was not able to see all the kitchens and therefore not able to appreciate all the conditions. Another time I wotld select some one kitchen and let all work on the same problem.

Some of the topics in which the pupils displayed unusual interest were: 1. Disposal of household wastes. 2. Cleaning agents. 3. The laundry. 4. Scientific management as outlined by Mrs. Fredericks in The New Housekeeping. 